Volume 1 Issue 1, March 2017: pp. 1-32. Copyright (c) 2017 HOLREV. Faculty of Law, Halu Oleo University, Kendari, Southeast Sulawesi, Indonesia. ISSN: 2548-1762 | e-ISSN: 2548-1754. Open Access at: http://ojs.uho.ac.id/index.php/holrev/

Halu Oleo Law Review is licensed under a Creative Commons Attribution 4.0 International License, which permits unrestricted use, distribution, and reproduction in any medium, provided the original work is properly cited.

\title{
Good Governance: Importance in Practice, Theories and Definitions
}

\author{
G. H. Addink \\ Hoogleraar \\ Departement Rechtsgeleerdheid - Staatsrecht, \\ Bestuursrecht en Rechtstheorie \\ E-mail: g.h.addink@uu.nl
}

\begin{abstract}
This work addresses at exploring appropriate method in applying the principle of good governance; importance in practice, theories and definitions. This effort is importance to understand in more detail the three dimensions of good governance. The relationship between good governance and national prosperity is not always clear and opinions vary across countries. But it is seen that good governance is important for the economic and social development of countries and promotion of good governance also creates more open and democratic societies. For that reason, this work offers the three dimensions of good governance: the rule of law, the democracy, and the institutional dimension. The solution of this method would precisely construct a holistic and integrated strategy in managing and optimizing collective strategic resources.
\end{abstract}

Keywords: Good Governance; Practice; and Theories

\section{INTRODUCTION}

Good governance is of growing importance for the prosperity of countries. To understand this relation, we first explain in more detail the three dimensions of good governance: the rule of law, the democracy, and the institutional dimension. The next step is to look at the principles of good governance, as parts of the motor of good governance. Some examples illustrate the application and practices of the principles and values of good governance in the member states. Finally, special attention is given to the relation between good governance and integrity. 


\section{ANALYSIS AND DISCUSSION}

\section{Importance of Good Governance in the Practice of States}

\section{Three dimensions, values and principles, and integrity}

Good governance is increasingly seen as a key factor in ensuring national prosperity, as it creates reliability, predictability and accountability. The relationship between good governance and national prosperity is not always clear and opinions vary across countries. But it is seen that good governance is important for the economic and social development of countries and promotion of good governance also creates more open and democratic societies. Therefore, it is important to learn lessons about the importance of good governance, the potential weakness of governance exposed by the financial crisis and how to respond to these weaknesses. What are the key aspects of good governance and are these universal or characteristic of individual countries? What is the role of factors such as the rule of law, transparency and accountability?

Good governance is a general concept in which we can distinguish three groups of values: The first group is the rule of law related values, the second group is the democracy related values and the third group is the group of modern institutional and constitutional values. These values can be seen as sources in the further development of the concept of Good Governance. In that development, we distinguish here three main lines or dimensions: 1 . Rule of law; 2. Democracy; 3. Institution.

\section{Rule of law dimension}

\section{Institutional dimension}

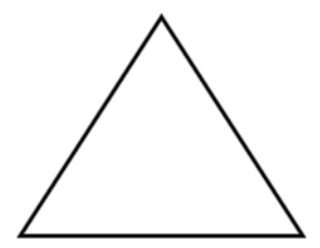

For each of these dimensions we are interested in the operationalization like what are the steering elements of the rule of law? How can democracy be realized? And, what are conditions for institutional functioning.

The three groups of values have been developed further into six principles. The rule of law related principles are properness and human rights, the democracy related principles are transparency and participation and the modern value related principles are 
effectiveness and accountability. These principles are interlinked in theory in many different ways; here we focus on the most remarkable links.

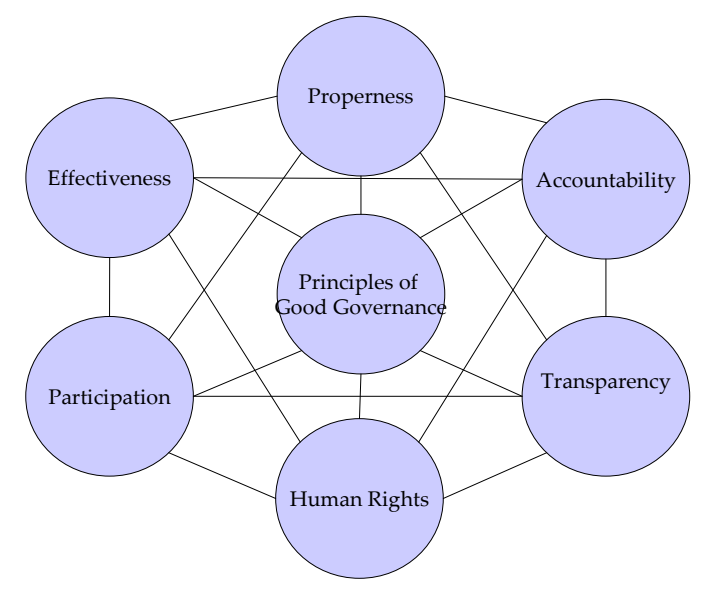

It is also important to ask attention for the situation that the principles of good governance have been developed by different institutions and from different perspectives. In a more instrumental way these principles are instrumental norms for the administration, but good governance principles are also used in a controlling way by the controlling institutions, as norms for review. The legislation and the administrative regulation (including the policy rules in which principles have been implemented) are more related to the instrumental dimension of good governance; the controlling function of the judiciary and the ombudsman, and in a certain way also the court of audit, are using good governance principles as controlling norms. Put more simply, the first and the second powers are more focused on the instrumental dimension of good governance and the third and the fourth powers are more focused on the controlling dimension of good governance.

\section{Functions and structure state in relation to shifts in development good governance}

In a state, we distinguish different powers and, in essence, each power of the state is working on the development of good governance norms. The development of the principles of good governance is strongly related to the function and structure of these institutions. The legislator mostly works on the development of good governance principles by writing general binding regulations containing norms with an instrumental character and norms protecting citizens. The administration tries to do so by instrumental norms in regulations including the codification of principles in policy rules or in internal directives which sometimes take the form of regulations or codes. But also in individual cases these principles are applied by the administration in other ways, for instance by 
requesting participation of the public in the decision-making process. The judiciary in particular is applying the principles of good governance in concrete cases by using them as norms for review. That is similar to how the ombudsman mostly works, which results in informal solutions or reports. The court of audit is applying these principles as review norms in relation to more general budget questions.

These principles are partly unwritten principles but more and more we find these principles in a written form in the constitutions, in the law, regulations, policy rules, directives, codes, case decisions, ombudsman reports and reports of the courts of audit. They are produced by institutions belonging to the first power in the state (legislator), the second power (the executive or administration), the third power (the judiciary) and the fourth power (the ombudsman, court of audit and the council of state). The legislator and the administration have a more instrumental character and the third and fourth powers are more related to the position of citizens. But they all produce good governance norms and they interact with each other. The good governance developments on decentralized level are also very relevant in this context and - of course - the developments in the frame of the European Union and the international organizations.

\section{Practices principles good governance in the member states}

This subject requires distinguishing between applications and practices of good governance as separate objects of study. We must also look at what means are employed to pursue good governance and how these means are understood against the background of the whole national legal system. It is exactly at this point where underlying domestic values come into play. This is why each country should be studied separately first.

In the country reports based on desk-studies and some email communication with experts in the countries, all EU-countries were object of research. In the introduction of each country report, attention was given to the geographical and historical development of the country and the structure and the powers of the state. This information was relevant to find out if and where the concept of good governance and the specification can be found in the country. The products of the government were studied to find out how the principles of good governance are specified and how the instrumental and the controlling approach of good governance interact. Not only these more general lines of the specification of principles but also concrete cases were described to understand more clearly how these principles were operationalized in practices. These cases were related to each of the 
following combination of policy fields: 1 . health and/or social policy; 2 . Economic and/or financial policy; 3. Environmental and infrastructure policy; and 4. Education policy and/or policy on justice. An indication of good governance is formulated based on this information.

Then we come to the second, more substantial question of the meaning of application and practices of good governance, in which the understanding of the concept of good governance is in the end most essential. Therefore, it is necessary to emphasize the bond between values and principles. Good governance is operationalized through the principles of good governance. These principles represent certain elements of good governance, but may also differ as to character. The latter refers to the different ways in which the principles are realized as to different modes of legislation and judicial interpretation. Principles of good governance are usually laid down in policy documents, which are not generally binding, but can have a binding effect when such documents bear a sufficiently formal character. However, policy documents that have no direct legal effect may still be to a certain extent binding through the principles of proper administration. A different situation exists when a Code is meant to be exemplary to other governmental institutions.

We have seen that good governance entails values for public governance especially related to institutions fulfilling a public task. This concept manifests itself in several principles in different fields of study: legal principles, policy principles, and economic principles. Legal principles are divided into general principles and other principles. General principles refer to fundamental ideas concerning the order in society. Yet even when principles are vague, they represent underlying values of the national legal system. As a consequence, these can be looked at when interpreting the law. Some other principles are not really fundamental, but yet invaluable and therefore normative to the legal system. Can we find some indication of these principles? Van den Brink spoke about freedom, fairness, equality, independence, participation and dignity. In the public administration context about the quality of the administration the following norms are often used integrity, honesty, objectivity and impartiality. These principles and norms should be linked to the three dimensions of good governance. 


\section{Relationship between good governance and integrity}

We have already noticed that the application of the principle of integrity expanded from the individual domain to the institutional domain. But there is something else going on. We see that these values have been increasingly frequent in the field of law. In international and European law, but also on national level, and in the general fields of constitutional, administrative and criminal law, but also in specific fields like municipality and civil servant law. The principle of integrity is found in the law, and this point to the link between law and good governance. There is not only a question of philosophical, ethical or historical perspective, but also of an administrative and legal perspective on integrity. This leads to interesting questions about the content of ethical and moral values of integrity, the question of the legal dimension of integrity, the relationship between these aspects and their evaluation by the classical administration itself and by independent external governmental agencies.

From an ethical perspective Huberts ${ }^{1}$ has classified - based on the literature and research - the various definitions of integrity into the following eight visions of integrity: 1.Integriteit als heelheid (integrity as wholeness); 2. Integriteit als passendheid (integrity as appropriateness); 3. Integriteit als professionele verantwoordelijkheid (integrity as professional responsibility); 4. Integriteit als bewust moreel reflecteren en handelen (integrity as a conscious moral reflection and action); 5. Integriteit als waarde(n) incl. onkreukbaarheid (integrity and value(s) including integrity); 6. Integriteit als overeenstemming met (waarden in) wet en regelgeving (integrity and compliance with (values of) law and regulations); 7. Integriteit als overeenstemming met geldende morele waarden en normen (Integrity and compliance with applicable standards and moral values); 8. Integriteit als exemplarisch ideaal gedrag (exemplary ideal behaviour).

These views are interesting because they show that the concept of integrity in the public sector can be seen from different angles. In his contribution Huberts essentially goes to the following four distinct concepts of integrity: (a) integrity as ethical understanding, (b) integrity as a social concept, (c) integrity as a moral concept, and (d) integrity as a legal concept. These concepts could be applied either in the individual or organizational context of public sector.

1 Leo Huberts, The Integrity of Governance, What is, What we know, What is done and Where to go, Palgrave Macmillan Ltd, 2014; L.W.J.C. Huberts, Visies op integriteit, in: Integriteit: Integriteit en integriteitsbeleid in Nederland. (J.H.J. van den Heuvel, L.W.J.C. Huberts \& E.R. Muller), Deventer: Kluwer 2012, p. 22. 
From a legal perspective, the different normative frameworks for different parts of the government are relevant here. ${ }^{2}$ When it comes to norms of integrity, because of their different constitutional position, we have to distinguish between the political heads who have an election mandate, like ministers, deputies and councillors, the representatives of the citizens - parliamentarians - on local, provincial and national level, and the civil servants working on the three levels. But we also have to look to the outcome of the work done by those who are controlling these public institutions, like the court, the ombudsman and the court of audit, by their work done for the protection of citizens.

Some remarks about the terminology of integrity, ethics and values. What is the reason that so often the term integrity is used? It seems that the use of this word pictures behaviour that is appreciated. And indeed, the word integrity is linked to honesty, wholeness, and impartiality. But is it possible to be completely unbiased? In other words, when is a person prejudiced? It seems rather unlikely that there is anyone without a bias. Does the concept of integrity draw the correct picture or might it have a different content?

The following explanation is intended to clarify the relationship between integrity and ethics and values, and also integrity in relation to legal rules and legal principles. Ethics and morality are both related to norms and values. Norms and values are often mentioned as one entity while certain characteristics of the two concepts differ materially and therefore should be distinguished. Values are moral principles that have weight when making choices; they have experiences or characteristics which we seek to attain. Values are often formulated abstractly and positively. Standards keep more concrete rules for behaviour and are often formulated negatively. There is a distinction between moral norms, social norms and legal standards. Values are limitless, while standards necessarily draw a line. Standards force more people to conform. Standards would have a greater objectivity because their extent is determined, while values are subjective in nature. Values are "open" moral categories and may refer to multiple standards, and standards cannot always be traced to a specific value. Are standards indeed concrete and are values merely abstract? Are values positive and norms usually negative in nature? Are values more subjective in nature and are standards more objective? Clear answers may not be available, but an example could provide for some clarity.

2 G.H. Addink, De toetsing van integriteitsschendingen getoetst, in: S.C. Loeffen e.a. (eds.), Integriteit in politiek en bestuur. De (on)mogelijkheden van het recht (Staatsrechtconferentie 2013), Oisterwijk: Wolf Legal Publishers, 2014. 
An example of objectification can be found in a report of the Netherlands Academy of Science. First some generally accepted standards for academic practice can be found and then some violations of those standards are described in the paragraph with the title "Forms of violations of academic integrity". Scientific integrity consists of compliance with the general principles that must be adhered to in all branches of science. Some of these are: the careful execution of research and the publishing of relevant information, scientific research results should be published in literature accessible for the public, the scientific statements should be based on objective observation and logical reasoning, and in this sense value-free, the application of the results are not value-free and possible conflicts of interest should be made known timely. In mid-June 2012, the Netherlands Association of Universities has published comprehensive policies for academic integrity on its website. This includes a code with a national model for complaints on violation of scientific integrity and one national definition of violations of academic integrity. The Code provides details on the following five principles: precision, reliability, verifiability, impartiality and independence.

Based on this example we get some indication for answering the questions related to the principles of integrity and good governance and law. Integrity means in this context compliance with general principles that are endorsed. In the sector of social life, it involves compliance with objective standards of integrity. And this brings us to the question about the relationship between law and integrity. Law consists not only of legal regulation but also legal principles. A question that arises is: are principles in the context of integrity consistent with the principles that we know in law? Moreover, it raises the question: are the norms and values related to integrity absorbed by the principles developed in the framework of the law or should these (partly) be distinguished? Do those requirements thus get a different content? What about the scope of the absorbed principles?

The expansion of the number of contexts in which integrity plays a role is remarkable. We find the concept in business and in government, in public but also in private life and see a process of broadening the integrity context. The result is that the concept is less clear. Perhaps the meanings given to this term in a very abstract level from its various applications still come together, but at the application level, within individual contexts, that will certainly not be the case. This is partly due to the difference in scope to be given. The concept of integrity is sometimes based on a narrow interpretation, and other times it has a much broader meaning. Besides the aspects in the narrow perspective 
we find also other aspects like collegiality, reliability, responsiveness, objectivity, decency, effectiveness, and efficiency. This varying scope of the concept indicates the great importance of a precise definition in connection with the discussion between different disciplines. If we do not provide such a definition, then the concept of integrity becomes an amorphous and rather meaningless umbrella term, and there is great risk of not undertaking or misunderstanding it. Moreover, there is also from a legal standpoint a need for a clear definition so that clear legal standards can be put in place.

There is a difference between good governance and integrity. Integrity has both a legal and a moral component and is focused on (but not only) the actions and behaviour of the civil servants or public sector employees. As such, it includes some principles of good governance: properness, accountability, transparency or sometimes human rights. But good governance is much wider, as it includes the principles of citizen participation and scrutiny and also focuses on the human rights aspects of the conduct of state bodies and employees. In most of the country reports attention has been given to the implementation of fighting and preventing corruption, also in relation to promoting integrity and good governance.

The relationship between the ethical, legal and good governance perspectives in the public sector integrity. (Dadan Anwar, 2015)

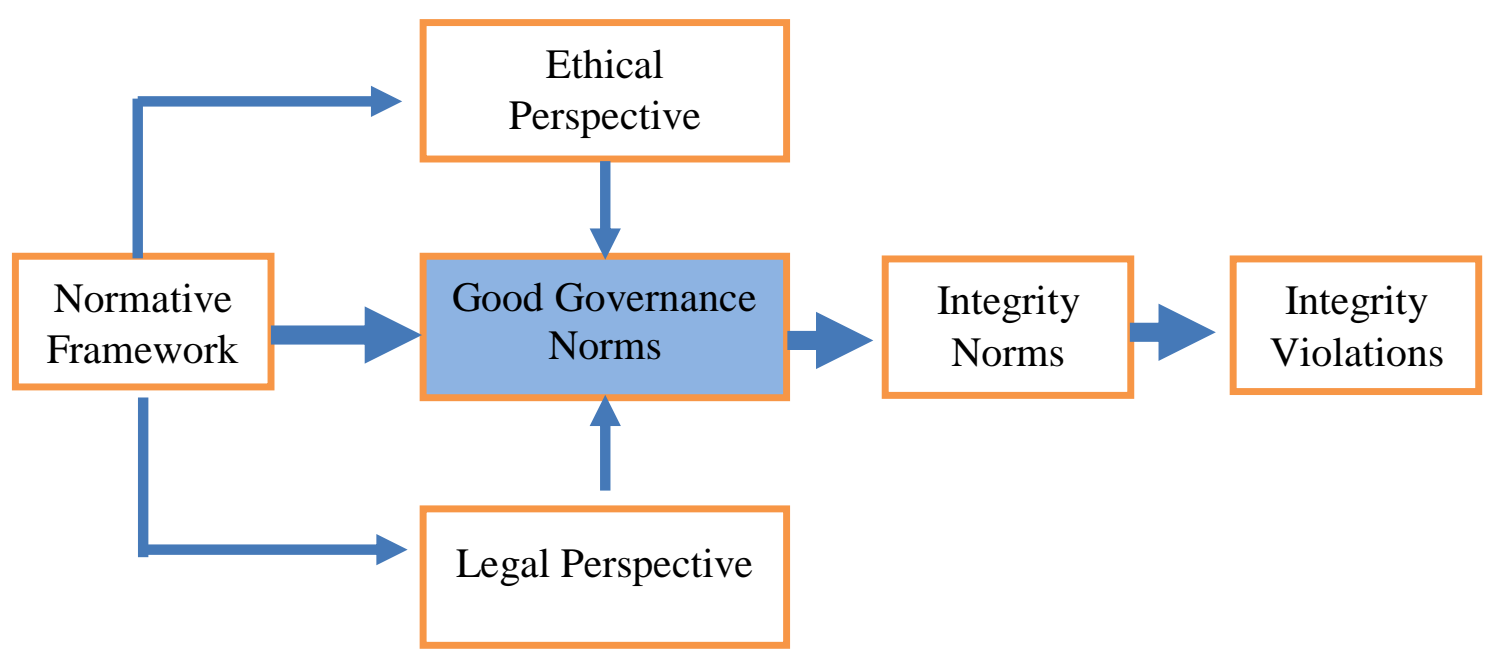

So, we see that integrity norms can be part of the good governance principles. But which principles are relevant in this context? To find out, we have to start with the right side of the picture: the violation of integrity norms. There we find two approaches. In the first, more classical approach integrity violation has especially to do with corruption and fraud in the context of the public and private sector. These notions have a specific content 
in criminal law. National Penal Codes often criminalize the active and passive bribery of domestic public officials, active and passive bribery in the private sector and active bribery during elections. ${ }^{3}$ Definitions of corruption and fraud are very important. In practice, the following definition of corruption in the public context has been provided: 'offering, giving, asking or receiving private gain because of the position or (non-)action of a public functionary'. Public functionaries are, in the context of penal law, civil servants as well as politicians, including governors and ministers. Elsewhere in the literature, there are many other definitions of corruption. ${ }^{4}$ The following aspects are relevant in relation to the definition of corruption: ${ }^{5}$ first, it is important to mention that the only relevant activities are those which are carried out in relation to the function of the person. So, purely private activities are not relevant for the discussion about the content of public corruption. Second, the interpretation of persons means that functionaries are civil servants, and so are politicians; 6 it concerns corruption in the public service. The third element of corruption is that there is a third party who will profit from the (non-)action of the civil servant and the civil servant will receive something in return for this (non-)action. This party will be mostly somebody outside the public organization. The fourth aspect is that we can speak about corruption in situations where there is not only a situation of receiving gifts, but also the prospect of receiving such gifts. ${ }^{7}$

3 Provisions on active and passive bribery sometimes also apply to national judges, former civil servants, foreign civil servants, international civil servants, foreign judges and judges of international organisations, as well as future civil servants.

4 Amsterdam Report 2005, Definitions, p. 4 report; the following authors gave their own definition of corruption: B.J.S. Hoetjes, Corruptie bij de overhead. Een bestuurlijk en politiek probleem, sociaal wetenschappelijk beschouwd, 's Gravenhage 1982; M. Johnston, The search for definitions: The validity of politics and the issue of corruption, International social science journal 1996, 149, p.321-335; L.W.J.C.Huberts, Bestuurlijke criminaliteit: Een inleiding, in: Bestuurlijke corruptie en fraude in Nederland, L.W.J.C. Huberts (ed.) 1992; A. Heywood, Politics, McMillan 1997; Gerald E. Caiden, O. P. Dwivedi, Joseph G. Jabbra, Where corruption lives, Kumarian Press 2001; A. J. Heidenheimer, Michael Johnston, Political Corruption, Concept \& Context, Transaction Publishers 2011.

5 See Amsterdam Report 2005, p. 4 et seq.

6 The notion of a civil servant has a broad interpretation in the case law (see HR 30 January 1914, W 9149; HR 1 December, NJ 1993, 354; HR 30 May 1995, NJ1995, 620) and according to the law (Art. 84 Penal Code in which it is explained that also members of parliament and members of city Councils are civil servants in this context). In the law special attention has been given to situations before and the situation after the fulfilling of the function of civil servant.

7 The definition provided here is more or less in line with the Dutch Penal Code, especially Articles 362 and 363. To explain this definition we have to study, first, these articles concerning gifts, promises or services and also the articles on bribery (Arts. 177 and 177a). ${ }^{7}$ Then we have to highlight the difference between corruption and fraud and what the limitations of these factual illegal activities exactly are. We will see that not only the negative qualifications (corruption and fraud) are relevant, but that for an administrative (preventive and repressive) approach we have to look at the standards which are relevant for the administration. These standards are especially integrity and the principles of good governance and these norms complete the national and international legal framework. But in administrative law we 
Often in a report a difference has been made between corruption and fraud; however, the two terms are related because both terms concern personal favors or promises. With regard to fraud there are two parties involved: the fraudster and the harmed person or institution. Corruption takes place between three parties: the civil servant who profits, the public organization and the person who induces the civil servant to benefit from his (non)actions. ${ }^{8}$ This difference can also be found in the administrative case law ${ }^{9}$ and administrative policy ${ }^{10}$ of the Netherlands.

There is in general an important difference in the Netherlands between the Penal Code and Administrative Legislation. In the Administrative Legislation, a distinction is made between a legal fact, a legal norm, a legal consequence, and a legal act. In the Penal Code attention is given to the punishable act and the punishment. From our point of view a fundamental point is lacking in the Amsterdam report: specifying the norm. We found only general reflections concerning integrity. In another report good governance principles were mentioned, but there was also no specification in relation to corruption. ${ }^{11}$ There is a need for a positive administrative law norm which can be found in the principles of good governance.

There is a second much broader approach of integrity violations which have been developed by van den Heuvel and Huberts ${ }^{12}$ and which have also been used by other authors.

The following types are distinguished:

1. Corruption, including bribing, 'kickbacks', nepotism, cronyism and patronage (with gain for oneself, family, friends or party).

2. Fraud and theft of resources, including manipulation of information to cover-up fraud.

have a more narrow definition of a civil servant and, as a consequence, also a more restrictive content of corruption in which there is only discussion about civil servants, politicians thereby being excluded.

8 See Amsterdam Report 2005, p. 5; See Amsterdam Report 2005, para. 1.2.1.;

9 Corruption: Central Appeals Tribunal 7 November 2002, 00/5791 AW, LJN AF3553; Fraud: Central Appeals Tribunal 13 November 2003, 02/1004 AW, 03/1535, LJN AN8809.

10 See about Fraud-policy: Kamerstukken (Parliamentary documents) II 2004/05, 17 050-29 810, nr. 295.

11 L.W.J.C. Huberts The Netherlands, Corruption and Anti-Corruption policies in the Netherlands, an evaluation, Transparency International, Berlin, 2001, p. 4.

${ }^{12}$ Huberts' classification has subsequently been used in research into the occurrence of integrity breaches in local government (J.H.J. van den Heuvel, L.W.J.C. Huberts and S. Verberk, Het morele gezicht van de Overheid: Waarden, normen en beleid, Utrecht 2002) and into the implementation of integrity policies in local government (J.H.J. van den Heuvel and L.W.J.C. Huberts, Integriteitsbeleid van gemeenten, Lemma 2003); L.W.J.C. Huberts What can be done against public corruption and fraud. Expert views on strategies to protect public integrity Law \& Social Change 29: 209-224, 1998. 


\section{Questionable promises, gifts or discounts.}

4. Conflict of interest through jobs and activities, outside the organization (e.g. 'moonlighting').

5. Improper use of violence towards citizens, suspects.

6. Other improper (investigative) methods of policing (including improper means for achieving noble causes).

7. Abuse and manipulation of information (unauthorized and improper use of police files; leaking confidential information).

8. Discrimination and (sexual) harassment; indecent treatment of colleagues/citizens.

9. The waste and abuse of organizational resources, including time.

10. Misconduct at leisure (domestic violence, drunken driving, use of drugs etc.).

This list of violations of integrity norms has been linked to some principles of good governance by Dadan Anwar (2015). The following principles of good governance are relevant in this context: properness, human rights, transparency and accountability.

The applicability of good governance norms in situation of integrity violations (Dadan Anwar, 2015)

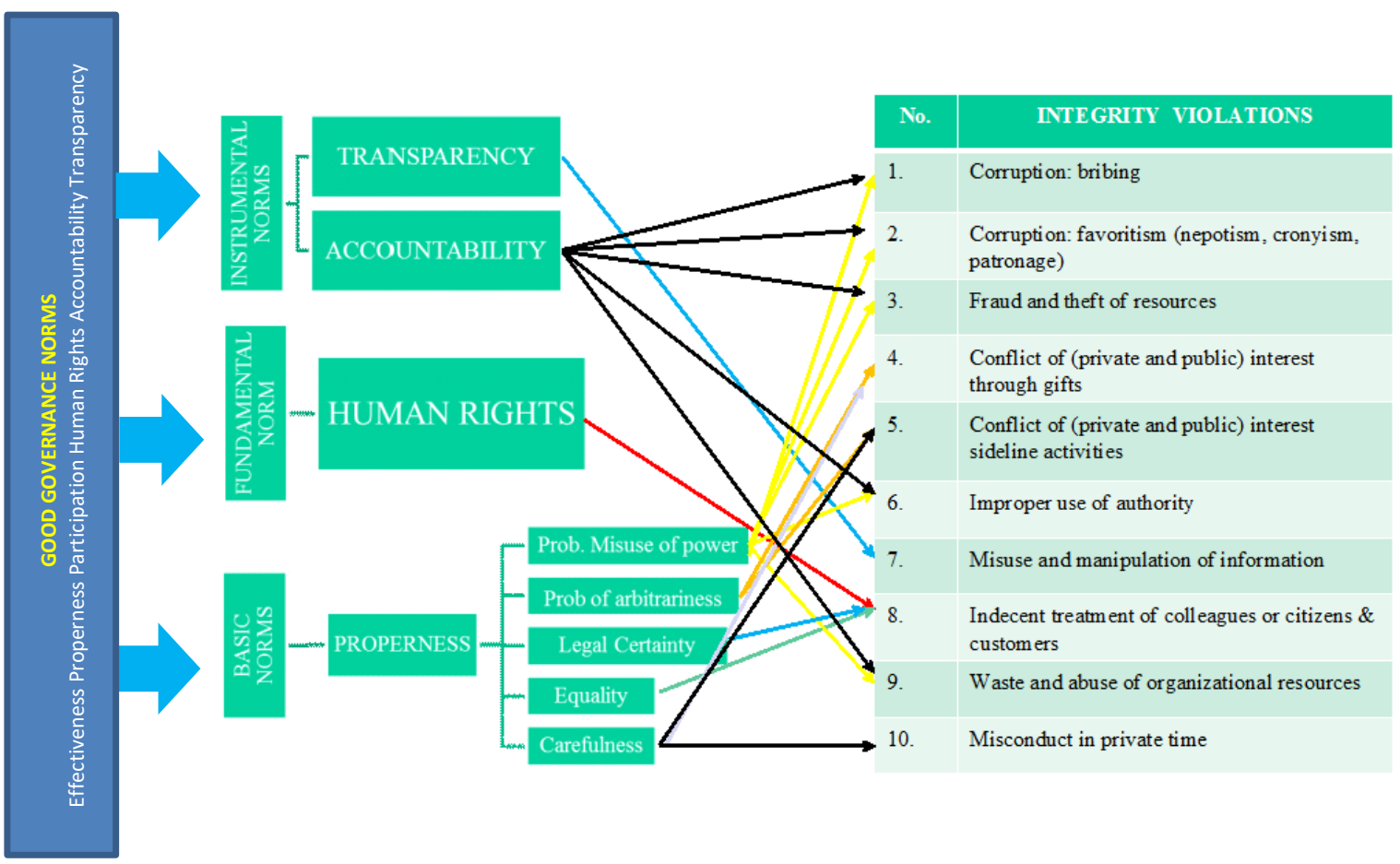

\section{Good Governance: Concepts and Sources}

In this chapter two concepts will be explained: the concept of good governance and the concept of the state. There is a close relation between these two concepts which can be found between government and governance. The good governance norms can be found in 
different legal different documents which each have their own binding effect which can be different for each of the forms. These forms will be illustrated by concrete examples.

\section{Concept of good governance}

The concept of good governance is not a purely legal concept. Several academic disciplines are involved, whether interdisciplinary or not, in the study of good governance. There are publications on interdisciplinarity between social science, economics, and law. ${ }^{13}$ For example, some social science researchers are preoccupied with a value charged approach to good governance. As for economics, mainly social economics are involved in the development of good governance. In the following, the role of the legal discipline is first elaborated. As all three disciplines overlap considerably, an integral interdisciplinary approach is needed to pursue further development of good governance and after that the non-legal disciplines. As to the legal discipline, three approaches are distinguished: the classical, the instrumental and the conceptual approach. The conceptual approach is especially interesting for good governance. This piece is to elaborate upon this, explaining three legal dimensions of good governance. These dimensions refer to the degree of abstractness of legal norms. The three dimensions are the meta conceptual, the macro regulation, and the micro review. ${ }^{14}$

\section{The meta conceptual dimension of good governance}

The meta conceptual dimension is the most abstract, the typical academic dimension which can be seen as a basic and fundamental normative framework also for the legal work in practice. This dimension includes the abstract relation between good governance, the rule of law, and democracy. This relation concerns concepts and some specific aspects. Legality and legitimacy, and respect for human rights illustrate the relation between the

13 G.H. Addink, Governance and Norms: An Interdisciplinary Approach of Good Governance, in: A.L.B. Colombo Ciacchi, M.A. Heldeweg, B.M.J. van der Meulen, A.R. Neerhof (eds.), Law \& Governance - Beyond the public-private law divide?), The Hague 2013, pp. 241-272; G.H. Addink, Goed Bestuur, inaugural lecture Utrecht University, chapter 5, p.19 ff.

14 G.H. Addink, Overview of Good Governance: overview and principles of properness (chapter 2, par. 2.3), in: Human Rights and Good Governance, SIM special 34, Utrecht 2010, p. 10, .http://www.uu.nl/faculty/leg/NL/organisatie/departementen/departementrechtsgeleerdheid/organi satie/onderdelen/studieeninformatiecentrummensenrechten/publicaties/simspecials/Documents/SI M Special 34.pdf. 
rule of law, democracy, and good governance. On both topics important discussions are going on in France. ${ }^{15}$

The first conceptual topic in the discussion is: what should be the consequences of the concept of good governance for the national legal system in general and the application of the principle of legality in particular from one side, and the development of a subjectification of the French case law from the other side. ${ }^{16} \mathrm{R}$. Bousta has written in her PhD-study 'Essai sur la notion de bonne administration en droit public'17 about the enrichment of the concept of legality based on the notion of 'la bonne administration'. One of the elements in this context is the enhancement of effectiveness. The second topic is concerned with good governance in the (administrative) review context, where the question is: should the focus be on the protection of subjective rights of the citizens or on the promotion of the objective norms? ${ }^{18}$ To date, the focus has been on the general interest as an objective norm and including the rigid legality approach. ${ }^{19}$ Good governance is according to some authors a general principle of law and article 41 of the EU Charter on fundamental rights should be seen as the final step in the completion of fundamental rights and obligations of human beings. Sometimes this is qualified as the process of subjectification of administrative litigation. Important in this discussion is to understand the legal autonomous character of good governance in the state, which will be operated by the instrument of administrative citizenship. The formalisation of a right to good governance assures the modernisation of administrative law and the administration by legal means.

15 J.M. Sauvé, L'avenir du modèle français de droit public en Europe, Conseil d'Etat 2011, http://chairemadp.sciences-po.fr/pdf/COLLOQUE/Intervention\%20l-avenir\%20du\%20modle\%20fran-ais\%20VD\%20-2-.pdf, last consulted 30-04-2015.

16 L'arrêt Perreux du 30 octobre 2009. In France three PhD-studies on Good Governance have been published: N. Marty, La notion de la bonne administration. A la confluence des droits européens et du droit administratif français, Montpellier 2007; J. Lassalle, Le principe de bonne administration en droit communautaire, Paris-2 2008; R. Bousta, Essai sur la notion de bonne administration en droit public, Paris 2010.

17 R. Bousta, Essai sur la notion de bonne administration en droit public, L'Harmattan Paris 2010, seconde partie, titre 2 .

18 M. Runavot, 'La bonne administration: consolidation d'un droit sous influence Européenne', RFDA, marsavril 2010, pp. 395-404.

19 B. Seiller, 'La renouvellement dans l'application du principe du légalité', in: La subjectivisation du contentieux administrative, Université Panthéon - Assas Paris II, par. II, 14 March 2011; B. Seiller, Droits publics subjectifs des administrés et transformations contemporaines du contentieux, in Les droits publics subjectifs des administrés, colloque de l'AFDA, Bordeaux, 2010, Litec, Colloques et débats, 2011, p.191. 


\section{The macro regulations dimension of good governance}

The macro regulations dimension concerns the codification of good governance in, for example, a Constitution, or a framework law of the central legislator. They mostly refer to the principles of properness, transparency, and accountability.

In France, we have seen the interrelation between the national and European law on the role of good governance as a fundamental right. This is especially interesting as the right to good administration and good governance is embraced in the European context. As to the relation between good governance and democracy, both have an interest in the principles of transparency and participation. Four types of participation illustrate this interrelationship, which are the citizen's initiative, the citizen's panel, community level participation, and the referendum. Different countries, regions, and municipalities use different types, but all types are related to a good performance of democracy. ${ }^{20}$ Still, some parliamentarians do not recognize the value of such additional aspects of direct democracy. Participation works best at the decentralized regional and local levels.

\section{The micro review dimension of good governance}

The micro review dimension concerns specific cases dealt with by the judiciary and ombudsmen in controlling the performance of the state's institutions. The Netherlands General Administrative Law Act (GALA) includes standards for micro-review by the court (art. 8:77) and the Ombudsman (art. 9:27):

'If the district court rules the appeal well-found, the judgment shall state what written or unwritten rule of law of general principles of law is considered infringed' (art. 8:77 GALA), and

'If it is the opinion of the ombudsman that the conduct was improper, he shall state in the report what standard of conduct was violated.' (art. 9:27 GALA).

Good governance can develop through the norms articulated. ${ }^{21}$ The judge's focus in on (un)written law and principles, and the ombudsman's on the norm of propriety.

20 G.H. Addink, Local and regional level participation in Europe, Utrecht University 2009; http://ec.europa.eu/dgs/secretariat general/citizens initiative/docs/provincie utrecht 1 en.pdf. See the country reports in the annex 1-5.

21 See publication of J.E.M. Polak, chair of the highest administrative court in the Netherlands, in the liber amicorum of Van Dijk. The development of general principles of good governance in Dutch administrative case law, in: Fundamental rights and principles; liber amicorum Pieter van Dijk; P. van Dijk, Marjolein van Roosmalen, G.J.H. van Hoof, M. Oosting, Cambridge UK: Intersentia, 2013 
We see not only on national but also on European level 22 and the international level ${ }^{23}$ these developments on the conceptual aspects of good governance but also on the controlling aspects which can be illustrated by a recent case of the European Court of Human Rights. ${ }^{24}$ The case was about the grant and revocation of a pension by the Polish government which was alleged violation of article 1 of protocol no.1 to the European Convention. The Court's assessment of the case was in two steps: according to the first step, such a public authority should act lawfully and pursue a legitimate aim by using means in reasonable proportion to the aims. In the second step, of application of the principles of lawfulness and in relation to the proportionality of the means the Court states:

"In examining the conformity of these events with the Convention, the Court reiterates the particular importance of the principle of good governance. It requires that where an issue pertaining to the general interest is at stake, especially when it affects fundamental human rights, including property rights, the public authorities must act promptly and in an appropriate and above all consistent manner (...). It is desirable that public authorities act with the utmost care, in particular when dealing with matters of vital importance to individuals, such as welfare benefits and other such rights. In the present case, the Court considers that having discovered their mistake, the authorities failed in their duty to act speedily and in an appropriate and consistent manner (...)".

A crucial element in this decision is that the Court reiterates the particular importance of the principle of good governance. It requires that when an issue pertaining to the general interest is at stake, especially when it affects fundamental human rights, including property rights, the public authorities have to act promptly, appropriately and above all consistently. It is the first time that the Court has reached a decision that is explicit about the fundamental character of the principle of good governance. But the Court did more, as it specified the norms for the Polish government and for public authorities in general. It is desirable that public authorities act with the utmost care, in particular when dealing with matters of vital importance to individuals, such as welfare benefits. In the present case, the Court considers that the authorities, after discovering their mistake, have

22 For those who are not that familiar with the European legal systems: European countries work together in the European Union which aims mainly concern the internal market and safety. The European Union is based on the treaty of Lisbon. Its Court is the European Court of Justice. Another institution is the Council of Europe, which aims mainly cover human rights and socio-cultural development. Its Court is the European Court of Human Rights which deals with claims based on the European Convention of Human Rights and its accompanying protocols.

23 G.H. Addink, Good Governance A Principle of International Law, in: What's Wrong with International Law (Cedric Ryngaert, Erik J. Molenaar, Sarah M.H.Nouwen, eds.) Leiden 2015, pp. 288-303.

24 ECHR October 2, 2012, nr. 5744/05, Czaja v. Poland. 
failed in their duty to act timely and adequately. The third element of relevance here is the proportionality analysis as presented by the Court. Now, we must explain the concept of the state and the link to the government and the activities of the different parts of the government in the context of good governance.

\section{Concept of the state and the link to government}

The state is sometimes defined as an organized community under one government and most often sovereign. But the state can also be used to refer to the branches of government within a state and the different types of states which can be distinguished. The two main types of states are the unitary and the federal states. Both types of states may be classified as sovereign states if they are not dependent on, or subject to, any other power or state. Other states are subject to external sovereignty or hegemony where ultimate sovereignty lies in another state.

In an unitary state, often decentralized units are created and abolished, and their powers may be broadened and narrowed, by the central government. Although political power in unitary states may be delegated through devolution to local government by statute, the central government remains supreme; it may abrogate the acts of devolved governments or curtail their powers. In federal states, by contrast, states or other sub national units share sovereignty with the central government, and the states constituting the federation have an existence and power functions that cannot be unilaterally changed by the central government. In some cases, it is the federal government that has only those powers expressly delegated to it. Many states are federated states which participate in a federal union. A federated state is a territorial and constitutional community forming part of a federation. Such states differ from sovereign states, in that they have transferred a portion of their sovereign powers to a federal government.

A state can be distinguished from a government. The government is the particular group of people, the administrative bureaucracy, which controls the state apparatus at a given time. That is, governments are the means through which state power is employed. States are served by a continuous succession of different governments. States are immaterial and nonphysical social objects, whereas governments are institutionalized groups of people with certain coercive powers. Each successive government is composed of a specialized and privileged body of individuals, who monopolize political decisionmaking, and are separated by status and organization from the population as a whole. 
Their function is to enforce existing laws, legislate new ones, and arbitrate conflicts. In some societies, this group is often a self-perpetuating or hereditary class. In other societies, such as democracies, the political roles remain, but there is frequent turnover of the people actually filling the positions.

\section{Different sources of good governance}

The good governance concept and the principles of good governance can be found in different sources of law. It is important to realize the legal character including the different legal binding effects of these sources can be different. Generally speaking, we find these aspects of good governance in constitutions, international treaties and law, in regulations explicitly based on the law and regulations implicitly or not at all based on the law, in individual administrative acts of the administrative authorities, the character of which can vary for each of them different. We find these norms of good governance also in decisions of the judiciary and in reports of the ombudsman and the court of audit. For each of the forms an example will be mentioned.

An example of good governance norms in the constitution can be found in Finland. Section 21 reads as follows:

'everyone has the right to have his or her case dealt with appropriately and without undue delay by a legally competent court of law or other authority, as well as to have a decision pertaining to his or her rights or obligations reviewed by a court of law or other independent organ for the administration of justice. Provisions concerning the publicity of proceedings, the right to be heard, the right to receive a reasoned decision and the right of appeal, as well as the other guarantees of a fair trial and good governance shall be laid down by an Act'.

The guarantee of good governance is mentioned in the context of protection under the law and the right to a fair trial. The section states that the guarantees of good governance shall be laid down by an act. From this provision, the guarantees of good governance and good administration are elaborated in further legislation. Thereby, the requirements of good governance are also protected by section 124 , which states that by delegating administrative powers to others than public authorities, the guarantees of good governance should not be endangered.

An example of a good governance norm in a treaty is Article 41 of Charter of Fundamental Rights in the European Union in which the Right to Good Administration has been specified: 
1. Every person has the right to have his or her affairs handled impartially, fairly and within a reasonable time by the institutions and bodies of the Union. 2. This right includes: the right of every person to be heard, before any individual measure which would affect him or her adversely is taken; the right of every person to have access to his or her file, while respecting the legitimate interests of confidentiality and of professional and business secrecy; the obligation of the administration to give reasons for its decisions. 3. Every person has the right to have the Community make good any damage caused by its institutions or by its servants in the performance of their duties, in accordance with the general principles common to the laws of the Member States. 4. Every person may write to the institutions of the Union in one of the languages of the Treaties and must have an answer in the same language.

Several principles of good governance can be found in policy papers. An example is the principles which have been specified in the Netherlands Code for Good Public Governance:

1. Openness and integrity. The executive body is open and honest, and makes clear what it takes those qualities to mean. The executive body conducts itself in such a way as to set a good example, both within the organisation and beyond it.

2. Participation. The executive body knows the public's concerns and interests, and makes clear how it is responding.

3. Appropriate contact with the public. The executive body ensures that it and the rest of the organisation act in an appropriate manner in their contacts with the public.

4. Effectiveness and efficiency. The executive body announces the objectives of the organisation and takes the decisions and measures necessary to achieve those objectives.

5. Legitimacy. The executive body takes the decisions and measures that it is empowered to take and that are in accordance with the applicable legislation and regulations. Those decisions can be accounted for.

6. Capacity for learning and self-improvement. The executive body improves its performance and that of the organisation, and structures the organisation in a way that ensures this.

7. Accountability. The executive body is prepared to render an account of itself to stakeholders, regularly and willingly.

An example of a decision of an international court, the International Court of Human Rights: in examining the conformity of events with the Convention, the Court reiterates the particular importance of the principle of good governance. 
"It requires that where an issue pertaining to the general interest is at stake, especially when it affects fundamental human rights, including property rights, the public authorities must act promptly and in an appropriate and above all consistent manner." ... "It is desirable that public authorities act with the utmost care, in particular when dealing with matters of vital importance to individuals, such as welfare benefits and other such rights. In the present case, the Court considers that having discovered their mistake, the authorities failed in their duty to act speedily and in an appropriate and consistent manner".

In the Netherlands Court of Audit Strategy 2010-2015 we find how good governance is interwoven with the work of this institution. ${ }^{25}$

The institution focuses on good governance to improve the learning ability of public administration. They aim to strike a balance between anticipating requests from those around the Court and investigating issues the Court feels are important in the light of their statutory task. As for good governance from the United Nations perspective, there are eight characteristics. These are arranged in clusters of two by the Netherlands Court of Audit: 1 . Democracy and rule of law; 2. Government performance and government operation. The particular focus is on the performance and operation of central government and its associated institutions. The four characteristics of good governance are: responsive, effective and efficient performance, and transparency and public accountability of operations. The Court uses these four characteristics to contribute to improvements in line with the Constitutional and statutory task and mission. In practice, the Court sees that performance and operation are closely interwoven. Whether or not an organisation is able to perform well depends in part on how well it operates. ${ }^{26}$

\section{Definitions: Government, Governance, Good Governance and Principles of Good}

\section{Governance}

In chapter 2 we spoke about the concepts of "governance" and of "state" and the relations between these two concepts and illustrated good governance norms in legally relevant documents from different governmental institutions acting in different capacities. In this chapter, the focus is on the definitions of the terms which are used in the context of this research: government, governance, good governance and principles of good governance.

\section{Government and governance}

Two aspects of governance have to be distinguished. The first is governance as an act of governing by persons or institutions. This relates to both decisions (public or private) that

25 http://www.courtofaudit.nl/english/Organisation/The Netherlands Court of Audit Strategy 2010 $\underline{2015}$.

26 Report Netherlands Court of Audit "Between Policy and Implementation. Lessons from recent research by the Netherlands Court of Audit (House of Representatives", session II 2002-2003, 28 831, nos. 1-2. 
define expectations, grant power, or verify performance - which have legal consequences - and factual acts. So governance concerns acts with both legal and non-legal effects.

The second aspect of governance is the process of bringing about each of these acts. This process consists of different phases in a procedure. These phases have sometimes been described in detail in the legal context, and other times they have been developed in case law. And as a consequence, we see differences in the description of phases in the respective policy fields. These procedural norms about each of the phases are binding.

Governance can be found inside a business or a non-profit organization: governance then relates to consistent management, cohesive policies, guidance, processes, and decision-rights for a given area of responsibility. For example, managing at a corporate level might involve evolving policies on privacy, on internal investment, and on the use of data. But one should distinguish between the activities that are done by the public institutions and the activities in the public interest pursued as part of a public task. The last category of activities, for which the governments have and keep a special responsibility in relation to the civil society, can be executed by private firms or non-profit organizations. Starting from the classical defending of the country and the public order, this public responsibility can nowadays also be discharged by governmental activities from non-governmental institutions (like private companies or NGOs) in the different policy fields such as public health, education, and the environment.

One should further distinguish between governance and government: as explained, governance is an integral concept of all the acts. The government is the competent institution to carry out these acts. These institutions are mainly public, but may also be business entities or private socio-political institutions, such as a families or tribes, and also NGO's. The term government is sometimes used abstractly as a synonym for governance, as in the Canadian motto, 'Peace, Order, and Good Government'.

\section{Origin of the word governance}

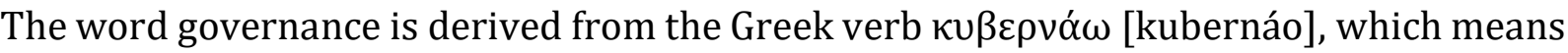
"to steer". This word was used by Plato for the first time as a metaphor. It passed on to Latin (gubernare) and was subsequently borrowed by many other languages. As a process, governance may operate in an organization of any size, from a single human being to all of humanity; and it may function for any purpose, whether good or evil, for profit or not. A reasonable or rational purpose of governance might aim to assure that an organization 
produces a worthwhile pattern of good results while avoiding an undesirable pattern of bad circumstances.

Perhaps the moral and natural purpose of governance consists of assuring, on behalf of those governed, a worthy design of good while avoiding undesirable consequences. The ideal purpose, obviously, would be to assure a perfect template of good without any negatively perceived consequences. A government comprises a set of interrelated positions which govern and exercise power, which can include coercive power. A good government, following this line of thought, could consist of a set of interrelated positions exercising coercive power that assures, on behalf of those governed, a worthwhile design of good results. But the government should also avoiding an undesirable pattern of unwanted circumstances, by making decisions that define expectations, grant power, and verify their performance. Politics provides for means by which the governance process operates. For example, people may choose expectations by way of political activity. They may grant power through political action and they may judge performance through political behaviour. Interpreting governance in this way, one can apply the concept to states, to corporations, to NGOs, to partnerships and other associations, to project teams, and to any number of humans engaged in some purposeful activity.

\section{Different definitions of governance}

The World Bank defines governance as the manner in which power is exercised in the management of a country's economic and social resources for development. ${ }^{27}$ The World Bank Government Indicators define governance as the traditions and institutions by which authority in a country is exercised. ${ }^{28}$ This considers the process by which governments are selected, monitored and replaced; the capacity of the government to effectively formulate and implement sound policies, the respect of citizens and the state of the institutions that govern economic and social interactions among them. An alternative definition explains governance as the use of institutions, structures of authority and even collaboration to allocate resources and to coordinate or control activity in society or the economy. ${ }^{29}$

27 http://info.worldbank.org/etools/docs/library/166856/UCMP/UCMP/session1-2_understanding.htm.

28 D. Kaufmann, A. Kraay \& M. Massimo, 'The Worldwide Governance Indicators: Methodology and Analytical Issues', World Bank Policy Research Working Paper, No. 5430, 2010 (September). Available at SSRN: <http://ssrn.com/abstract=1682130>.

29 S. Bell, Economic Governance and Institutional Dynamics, Melbourne: Oxford University Press 2002. 
According to the United Nations Development Programmes Regional Project on Local Governance for Latin America, governance has been defined as the rules of a political system to solve conflicts between actors and adopt decisions, which refers to legality. It has also been used to describe the 'proper functioning of institutions and their acceptance by the public', ${ }^{30}$ which is about legitimacy. And it has been used to invoke the efficacy of government and the achievement of consensus by democratic means. This corresponds to the principle of participation.

The state and politics; corporate organizations; three ways of governance

Some suggest making a clear distinction between the concepts of governance and of those of politics. Politics involves processes by which a group of people with initially divergent opinions or interests reach collective decisions generally regarded as binding on the group, and are enforced as common policy. Governance, on the other hand, conveys the administrative and process oriented elements of governing. Such an argument continues to assume the possibility of the traditional separation between politics and administration. Contemporary governance practice and theory sometimes question this distinction, premising that both governance and politics involve aspects of the exercise of power.

In general terms, governance appears in three broad ways. First, it appears through networks involving public-private partnerships or with the collaboration of community organizations. Second, by use of market mechanisms by which market principles of competition serve to allocate resources while operating under government regulation. Finally, through top-down methods that primarily involve governments and the state bureaucracy. These modes of governance - classical governance, market-oriented governance and partnership governance - often appear in terms of hierarchy, markets, and networks, but in democracies as well. Corporate organizations also often use the word governance to describe both the laws and customs applied by the corporation and the manner in which boards direct a corporation. Fair governance implies that mechanisms function in a way that allows the executives to respect the rights and interests of the stakeholders. In the following sections, we make some distinctions between the terms governance and administration; good governance and principles of good governance; and principles of good governance and principles of proper administration.

30 UNDP 2004; < http://www.ejolt.org/2013/02/environmental-governance. 


\section{Governance and administration}

With regard to principles, less of a difference is made between governance ${ }^{31}$ and administration, ${ }^{32}$ although their content may slightly differ. Governance from a legal dimension means as explained before all the three powers: legislative, executive and judicial. Furthermore, the definitions of both may be somewhat diffused. For example, political science uses many different meanings of governance. ${ }^{33}$ Of course, these meanings stem from specific approaches adhered to in political science. Who has the authority to determine a definition which can be generally applied? As to this point we find the critical remarks by the LSE Study Group on European Administrative Law. ${ }^{34}$

Both governance and administration are used here in the specific context of administrative law in which a public dimension of a specific competence is from a public law perspective most relevant. This recognition is crucial. ${ }^{35}$ In other contexts, governance may refer to non-public phenomena as well, for example the principles of corporate governance. We can still recognize comparable developments of the types of norms in these principles of corporate governance.

Public activities, however, are not only carried out by traditional administrative institutions, such as the province or a municipality, but also by independent administrative bodies and - under some conditions - by private institutions as long as their competence is derived from public law including tasks and they are not subordinated to other institutions in the exercise of their power. To all those actors, including the private institutions like companies and NGO's which are fulfilling public tasks, the principles of

31 In dictionaries, the following definitions have been provided for Governance: exercise of authority; control; government; arrangement. Two other brief descriptions of Governance are the following: 1 . the act, process, or power of governing; 2. the state of being governed. Two other descriptions: 1 . the persons (institution) who make up a governing body and who administer something; 2 . the act of governing, exercising authority.

32 In dictionaries, we find the following definitions of administration in a governmental context: 1 . the act or process of administering (management of a government); 2 . the activity of a government in the exercise of its powers and duties; 3. the executive branch of a government; 4 . office of an executive officer or body; 5. law management and disposal of a trust or estate; 6. dispensing, applying or tendering of something such as an oath.

33 Robert Rhodes found at least six usages for the term governance: R. Rhodes, 'The New Governance: Governing Without Government', Political Studies, 44, 1996, p. 652. This political scientist primarily makes reference to the methodology of government in the post-modern, minimal state $(=$ good governance); the other sets of meanings are concerned with systems analysis, socio-cybernetic systems and self-organising networks.

34 LSE Study Group on European Administrative Law, Taking Governance Seriously, March 2002, para. 1.

35 M.P. Chiti, 'Are there Universal principles of good governance?', European Public Law, Vol.1, Issue 2, 1995, pp.241-258; H. P. Nehl, Principles of Administrative Procedure in EC Law, Oxford and Portland Oregon: Hart Publishing 1999, p. 17. 
good governance are applicable. As far as administration is concerned, governance is here mainly linked with the principles of good governance.

Thus, governance is strongly connected with the methodology of the governmental activities in the postmodern minimal state, and covers the concept of good governance and the efficiency targets of new public management. ${ }^{36}$ As governance lacks a normative connotation, it is preferable to employ the terminology of good governance in the normative legal discussion.

\section{Principles of good governance and of proper administration}

An important difference exists between good governance and the principles of good governance. The principles of good governance have a strong normative connotation and may function instrumentally, whereas good governance is the underlying concept and the consequence of the observance of the principles. The literature varies in its terminology as to the principles of good governance. Sometimes the principles of proper or fair administration are used instead of the principles of good governance, which is not sufficiently precise. As the principles of good governance have a specific relevance to the administration, one may use the terminology of the principles of good administration in the specific context of the administration. The European Ombudsman also refers to principles of good administration in his assessment of deemed maladministration. ${ }^{37}$ Principles of good administration include higher requirements ${ }^{38}$ than principles of proper and fair administration ${ }^{39}$ which constitute minimum standards. A violation of at least the latter would constitute illegality and unlawfulness.

\section{Good governance at national, regional and international level}

The concept of good governance is not only discussed in the context of European law, but also in the context of national and international law. The discussion is sometimes difficult to recognize as concerning good governance since the terminology and the applied set of principles differ. For this reason, it is important to have a common terminology and to apply a comparable set of principles, which of course may have a different relevance in

36 LSE Study Group on European Administrative Law, Taking Governance Seriously, March 2002, para. 1.; R. Rhodes, 'The New Governance: Governing Without Government', Political Studies, No.44, 1996, p. 652.

37 Art. 195 EU Treaty.

38 Properness, transparency, participation, effectiveness, accountability, and human rights; G.H. Addink, Goed Bestuur, Kluwer Deventer, 2010, p. 28; G.H. Addink, Good Governance, in G.H. Addink et al. (eds.), Human Rights and Good Governance, Utrecht, 2010, pp.11-134.

39 Principles of fair administration are of the same level as proper administration. 
each context. Nevertheless, there are some comparable tendencies in the discussions on good governance in fields of administrative, international and European law.

In relation to the international law debate, we would like to reiterate the different definitions of good governance which are provided by international institutions such as the UNDP, ${ }^{40}$ UNCHR, ${ }^{41}$ OECD, ${ }^{42}$ IMF, ${ }^{43}$ and the World Bank. ${ }^{44}$ These institutions all work with the notion of good governance. Here, the principles of good governance have functioned as an external field of normative reference. In any case, the character of the discussions seems to go further than the legal field; therefore, the different academic disciplines had to cooperate to develop a consistent system of good governance, including the legal embedment. ${ }^{45}$ In literature the idea of good governance as a principle of international law has been developed. ${ }^{46}$

\section{Good governance and the juridification of integrity}

How should we evaluate the increasing attention from the field of law for those aspects which originated as ethical and moral standards? On a legal-theoretical level they were already always interested which can be seen in the discussion on the distinction between ethical and moral principles and the legal principles in the context of the discussion on fundamental legal principles. ${ }^{47}$ But now we also increasingly see the interest of those who have a more positive legal approach. ${ }^{48}$ That attention is mainly driven from an instrumental

40 UNDP policy document, Governance for Sustainable Human Development, 1997.

41 UNCHR Resolution 1998/72.

42 OECD Development Assistance Committee, Part I and Part II, Paris 1997; OECD, Governance in the $21^{\text {st }}$ Century, Paris 2001.

43 IMF, The IMF and Good Governance, 2002.

44 World Bank, Good Governance and Fiscal Transparency, 1994; World Bank, Corruption and Good Governance, 1997.

45 Foqué who used the terms 'General Principles of Good Global Governance': see R. Foqué, 'Global Governance and the Rule of Law. Human Rights and General Principles of Good Global Governance', inL K. Wellens (ed.), International Law: Theory and Practice: Essays in Honour of Eric Suy, The Hague: Martinus Nijhoff Publishers 1998, p. 39.

46 G.H. Addink, Good Governance A Principle of International Law, in: What's Wrong with International Law (Cedric Ryngaert, Erik J. Molenaar, Sarah M.H.Nouwen, eds.) Leiden 2015, pp. 288-303.

47 Key to Ronald Dworkin's Constructive Interpretation of legal practice is the conception of Law as Integrity. Law as integrity holds a vision for judges which states that as far as possible judges should identify legal rights and duties on the assumption that they were all created by the community as an entity, and that they express the community's conception of justice and fairness. According to law as integrity, proposition of law are true if they figure in or follow from the principles of justice, fairness and procedural due process, which provide the best constructive interpretation of the community's legal practice.

48 Originally the focus was restricted to art. 2:4 of the Netherlands General Administrative Law Act (GALA) - 1./ An administrative authority shall perform its duties impartially. 2. An administrative authority shall ensure that persons associated with or working for it who have a personal interest in a decision have no 
point of view in which there is also a need to anchor the ethical and moral standards and values in law with legal enforcement mechanisms. It then proceeds to monitor the compliance with those standards and to the sanctioning violations of these norms through administrative or criminal enforcement mechanisms. Then there is the development of another kind of legal instruments, namely a set of instruments aimed at the preventing the violation of the integrity requirements, including corruption..$^{49}$ Some of these instruments are the different codes in the area of integrity and good governance.

In relation to the integrity actors, in addition to the discussion on integrity and good governance in relation to civil servants and politicians, there is also a discussion going on about judicial integrity. That would be an important argument - instead of a limited understanding - to aim for a broader concept of good governance which includes all State actors. In short, besides administrative integrity, there is also the discussion on judicial integrity; ${ }^{0}$ but legal questions also arise regarding integrity in businesses. This contribution focuses on the administrative-legal integrity, so integrity aspects which are related to those who work in the public administration.

\section{External supervision of integrity and good governance}

In addition to the interpretation and the development, by the administration itself (the internal perspective), of requirements of integrity and good governance in relation to each other, and their enforcement, we also see increasing attention from outside the public administration (the external perspective). Checking and assessing these requirements shall be carried out by independent bodies such as courts ${ }^{51}$, the Court of audit ${ }^{52}$ and the National Ombudsman ${ }^{53}$. That development is not irrelevant because a judgment is given in an independent way; thus, what it has to say about the standards of integrity and good governance will be further developed.

influence on decision-making in the matter - later the focus was broader and related to all the good governance norms codified in the GALA.

49 See the letter of the Minister of Interior of July 11, 2012 to the parliament about the GRECO evaluation which was focus on the prevention of corruption in the Netherlands.

50 A.F.M. Brenninkmeijer, De instrumentele rechter, NJB 2011, p. 1056; A. van 't Laar, De ongekreukte rechter?, in: N.J.H. Huls (red.), Ongedeeld integer, Den Haag: BJu 2009; J.E. Soeharno, J.E., The integrity of the judge: A philosophical inquiry, diss. Utrecht University, Farnham 2009; J.E. Soeharno, J.E., Blind vertrouwen: De norm van rechterlijke integriteit, Rechtstreeks 2011, Den Haag.

51 See specifc case law Central Appeals Tribunal about art.125ter Ambtenarenwet (Civil Servant Act) and the more general case law about principles of proper administration.

52 Report of the Court of Audit, March 25, 2010, Situation Integrity Central Government 2009, II, 2009-2010, 32341, nrs. 1-2.

53 I. Mos, Integrity according to the National Ombudsman, Master thesis Utrecht University, February 2011. 
The juridification of integrity also raises a more fundamental issue: How do the requirements from the legal perspective (written and unwritten law) link to the requirements coming from the ethical and philosophical perspective? To answer that question satisfactorily will depend on the perspective and the focus. Enlightening for the discussion is in any case a clear view of the contents of the terms to prevent misunderstandings about the conceptual frameworks which are used by the various disciplines. Relevant is a clear view on the relationship between integrity and good governance and through an integration of the legality of integrity with the legal aspects of good governance we obtain a more complete picture of the meaning of the concept of integrity through good governance.

\section{CONCLUSION}

Good governance and good administration are theoretically not the same. Governance can be seen as the work of the government, which consists of all the powers in the state: the legislative, the executive (administrative) power, the judicial power and the fourth power such as the ombudsman and courts of audits. But all the powers in the state have a function in relation to the work of the administration - the classic administration but also other sometimes independent institutions fulfilling a public task. Therefore, we can say in this research that when we speak about good governance it is especially good governance related to the administration and therefore we do not distinguish here between good governance and good administration. In addition, in general concept, it can be distinguish three groups of values; Rule of law, Democracy, and Institution. These values can be seen as sources in the further development of the concept of Good Governance.

\section{Bibliography}

\section{Books}

Addink, G.H, De toetsing van integriteitsschendingen getoetst, in: S.C. Loeffen e.a. (eds.), Integriteit in politiek en bestuur. De (on)mogelijkheden van het recht (Staatsrechtconferentie 2013), Oisterwijk: Wolf Legal Publishers, 2014.

------, et al. (eds.), Good Governance, Human Rights and Good Governance, Utrecht, 2010.

-------, Goed Bestuur, Inaugural lecture Utrecht University, chapter 5, 2010. 
------, Good Governance A Principle of International Law, in: What's Wrong with International Law (Cedric Ryngaert, Erik J. Molenaar, Sarah M.H.Nouwen, eds.) Leiden 2015.

, Governance and Norms: An Interdisciplinary Approach of Good Governance, in: A.L.B. Colombo Ciacchi, M.A. Heldeweg, B.M.J. van der Meulen, A.R. Neerhof (eds.), Law \& Governance - Beyond the public-private law divide?), The Hague 2013.

------, Local and Regional Level Participation In Europe, Utrecht University 2009.

-, Overview of Good Governance: Overview And Principles Of Properness (chapter 2, par. 2.3), in: Human Rights and Good Governance, SIM special 34, Utrecht 2010.

-------, Properness, Transparency, Participation, Effectiveness, Accountability, and Human Rights; Goed Bestuur, Kluwer, Deventer, 2010.

-------, 'The Ombudsman as the fourth power. On the foundations of Ombudsman law from a comparative perspective', in: E.C.H.J. van der Linden \& F.A.M. Stroink (eds.) Judicial Lawmaking and Administrative Law, Ius Commune Europaeum Vol. 52 (Intersentia 2005). Sometimes the civil servants or the media re qualified as the fourth power: R. Crince Le Roy, De vierde macht: de ambtelijke bureaucratie als machtsfactor in de staat (VUGA 1969); R. Crince Le Roy, De vierde macht. Een hernieuwde kennismaking (VUGA 1976); M.A.P. Bovens, De vierde macht revisited, Utrecht University, 2000.

Bell, S., Economic Governance and Institutional Dynamics, Melbourne: Oxford University Press 2002.

Bousta, R, Essai sur la notion de bonne administration en droit public, L'Harmattan, seconde partie, titre 2. Paris 2010.

Brenninkmeijer, A.F.M, De instrumentele rechter, NJB 2011, p. 1056; A. van 't Laar, De ongekreukte rechter?, in: N.J.H. Huls (red.), Ongedeeld integer, Den Haag: BJu 2009;

Chiti, M.P., “Are there Universal principles of good governance?', European Public Law, Vol.1, Issue 2, 1995.

Foqué, R., 'Global Governance and the Rule of Law. Human Rights and General Principles of Good Global Governance', inL K. Wellens (ed.), International Law: Theory and Practice: Essays in Honour of Eric Suy, The Hague: Martinus Nijhoff Publishers 1998.

Heidenheimer, A. J. \& Michael Johnston, Political Corruption, Concept \& Context, Transaction Publishers 2011. 
Hoetjes, B.J.S, Corruptie bij de overhead. Een bestuurlijk en politiek probleem, sociaal wetenschappelijk beschouwd, 's Gravenhage, Amsterdam Report 2005.

Huberts, Leo, The Integrity of Governance, What is, What we know, What is done and Where to go, Palgrave Macmillan Ltd, 2014; L.W.J.C. Huberts, Visies op integriteit, in: Integriteit: Integriteit en integriteitsbeleid in Nederland. (J.H.J. van den Heuvel, L.W.J.C. Huberts \& E.R. Muller), Deventer: Kluwer 2012.

Huberts, L.W.J.C, Bestuurlijke criminaliteit: Een inleiding, in: Bestuurlijke corruptie en fraude in Nederland, L.W.J.C. Huberts (ed.) 1992; A. Heywood, Politics, McMillan 1997; Gerald E. Caiden, O. P. Dwivedi, Joseph G. Jabbra, Where corruption lives, Kumarian Press 2001.

-------, Integriteitsbeleid van gemeenten, Lemma, 2003.

------, the Netherlands, Corruption and Anti-Corruption policies in the Netherlands, an evaluation, Transparency International, Berlin, 2001.

------, Verberk, Het morele gezicht van de Overheid: Waarden, normen en beleid, Utrecht, 2002.

-------, What can be done against public corruption and fraud. Expert views on strategies to protect public integrity Law \& Social Change 29: 209-224, 1998.

Johnston, M, The search for definitions: The Validity of Politics and the Issue Of Corruption, International Social Science Journal 1996.

Lassalle, J, Le principe de bonne administration en droit communautaire, Paris-2 2008.

Marty, N, La notion de la bonne administration. A la confluence des droits européens et du droit administratif français, Montpellier, L'arrêt Perreux du: 30 Octobre 2009. In France three PhD-studies on Good Governance have been published 2007.

Mos, I, Integrity according to the National Ombudsman, Master thesis Utrecht University, February 2011.

Nehl, H. P, Principles of Administrative Procedure in EC Law, Oxford and Portland Oregon: Hart Publishing 1999.

Polak, J.E.M, Chair of the highest administrative court in the Netherlands, in the liber amicorum of Van Dijk. The development of general principles of good governance in Dutch administrative case law, in: Fundamental rights and principles; liber amicorum Pieter van Dijk; P. van Dijk, Marjolein van Roosmalen, G.J.H. van Hoof, M. Oosting, Cambridge UK: Intersentia, 2013 
Rhodes, R, 'the New Governance: Governing Without Government', Political Studies, 44, 1996.

Runavot, M, 'La bonne administration: consolidation d'un droit sous influence Européenne', RFDA, Mars-Avril 2010.

Seiller, B, Droits publics subjectifs des administrés et transformations contemporaines du contentieux, in Les droits publics subjectifs des administrés, colloque de l'AFDA, Bordeaux, 2010, Litec, Colloques et débats, 2011.

-, 'La renouvellement dans l'application du principe du légalité', in: La subjectivisation du contentieux administrative, Université Panthéon - Assas Paris II, par. II, 14 March 2011.

Soeharno, J.E., The integrity of the judge: A philosophical inquiry, diss. Utrecht University, Farnham 2009;

, Blind vertrouwen: De norm van rechterlijke integriteit, Rechtstreeks, Den Haag, 2011.

\section{Internet \& Journals}

ECHR October 2, 2012, nr. 5744/05, Czaja v. Poland. Principles of fair administration are of the same level as proper administration.

http://chairemadp.sciences-po.fr/pdf/COLLOQUE/Intervention\%201-

avenir\%20du\%20mod-le\%20fran-ais\%20VD\%20-2-.pdf, last consulted 30-042015.

http://ec.europa.eu/dgs/secretariat_general/citizens_initiative/docs/provincie_utrecht_

1_en.pdf. See the country reports in the annex 1-5.

http://info.worldbank.org/etools/docs/library/166856/UCMP/UCMP/session1-

2_understanding.htm.

http://www.courtofaudit.nl/english/Organisation/The_Netherlands_Court_of_Audit_Stra tegy_2010_2015.

http://www.uu.nl/faculty/leg/NL/organisatie/departementen/departementrechtsgelee rdheid/organisatie/onderdelen/studieeninformatiecentrummensenrechten/publi caties/simspecials/Documents/SIM_Special_34.pdf.

IMF, The IMF and Good Governance, 2002.

J.M. Sauvé, L'avenir du modèle français de droit public en Europe, Conseil d'Etat 2011. 
Kaufmann, D.A. Kraay \& M. Massimo, 'the Worldwide Governance Indicators: Methodology and Analytical Issues', World Bank Policy Research Working Paper, No. 5430, 2010 (September). Available at SSRN: <http://ssrn.com/abstract=1682130>.

LSE Study Group on European Administrative Law, Taking Governance Seriously, March 2002, para. 1.; R. Rhodes, 'The New Governance: Governing Without Government', Political Studies, No.44, 1996.

LSE Study Group on European Administrative Law, Taking Governance Seriously, March 2002.

OECD Development Assistance Committee, Part I and Part II, Paris 1997; OECD, Governance in the $21^{\text {st }}$ Century, Paris 2001.

Report Netherlands Court of Audit "Between Policy and Implementation. Lessons from recent research by the Netherlands Court of Audit (House of Representatives", session II 2002-2003.

Report of the Court of Audit, March 25, 2010, Situation Integrity Central Government 2009, II, 2009-2010.

The Minister of Interior of July 11, 2012 to the parliament about the GRECO evaluation which was focus on the prevention of corruption in the Netherlands.

UNCHR Resolution 1998/72.

UNDP 2004; http://www.ejolt.org/2013/02/environmental-governance.

UNDP policy document, Governance for Sustainable Human Development, 1997.

World Bank, Good Governance and Fiscal Transparency, 1994; World Bank, Corruption and Good Governance, 1997. 